\title{
Praktyczny przewodnik EHRA a stosowanie NOAC w świetle nowszych dokumentów
}

\author{
prof. dr hab. n. med. Krzysztof J. Filipiak \\ I Katedra i Klinika Kardiologii, Warszawski Uniwersytet Medyczny, Warszawa
}

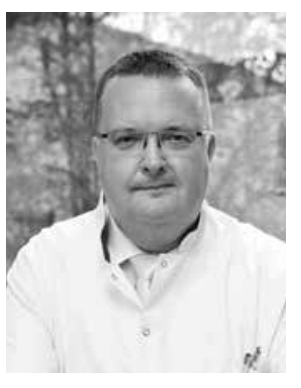

Jak podkreśla w swoim komentarzu ekspert w dziedzinie elektroterapii — prof. Przemysław Mitkowski - nowy praktyczny przewodnik European Heart Rhythm Association (EHRA) nie stanowi formalnego zalecenia, ale i tak jest traktowany w Europie z właściwym szacunkiem i dla wielu osób jest źródłem wskazówek do postępowania terapeutycznego związanego z doustnymi antykoagulantami niebędącymi antagonistami witaminy $\mathrm{K}$ (NOAC, non-vitamin K antagonists oral anticoagulants). Z kolei, chociaż upłynął niemal rok od rozpropagowania tego dokumentu i wiedza o NOAC stale się poszerza, to wiele kwestii pozostaje nadal nierozwiązanych.

Dlatego też narodowe towarzystwa kardiologiczne powołują grupy robocze lub eksperci spontanicznie tworzą wytyczne i rekomendacje, których nie można lekceważyć. W Polsce już po zaleceniach EHRA ukazało się ważne stanowisko ekspertów Sekcji Farmakoterapii Sercowo-Naczyniowej Polskiego Towarzystwa Kardiologicznego (PTK), które koresponduje z treścią przewodnika EHRA, więc chciałbym je krótko skomentować [1].

Autorzy polskiego stanowiska dokładnie omówili różne praktyczne aspekty stosowania NOAC, a na końcu dokumentu umieścili „dekalog” informacji do zapamiętania, który brzmi następująco:

1. Leki przeciwzakrzepowe nowej generacji - NOAC - powinny być preferowanym wyborem w zapobieganiu zatorowości sercopochodnej i żylnej chorobie zakrzepowo-zatorowej (zatorowości płucnej). Przeciwwskazaniami do stosowania NOAC są: mechaniczna zastawka serca, istotne zwężenie zastawki mitralnej i zaawansowana niewydolność nerek ze współczynnikiem przesączania kłębuszkowego (GFR) $<15 \mathrm{ml} / \mathrm{min}$. Komentarz: NOAC są dzisiaj lekami pierwszego wyboru w swojej klasie. Takie zdanie w odniesieniu do migotania przedsionków nie budzi aktualnie wątpliwości (patrz: europejskie wytyczne dotyczące leczenia migotania przedsionków opubli- kowane w sierpniu 2016 r.) [2], ale w stosunku do zatorowości płucnej/żylnej choroby zakrzepowo-zatorowej jest ono wyraźną deklaracją ekspertów, który sposób terapii przeciwkrzepliwej najlepiej wybrać. Interesujące jest podejście do nerkowego progu bezpieczeństwa stosowania NOAC — mimo różnic w wartościach GFR będących progiem bezpieczeństwa stosowania różnych NOAC, eksperci potraktowali te leki grupowo, uznając, że jedynie GFR < $15 \mathrm{ml} / \mathrm{min}$ stanowi przeciwwskazanie do podawania tej grupy leków; inne, wspomniane przeciwwskazania są wymienione na rycinie zamieszczonej w ostatnich wytycznych dotyczących leczenia migotania przedsionków, która przy okazji jeszcze raz pokazuje, które sposoby terapii przeciwkrzepliwej są preferowane (strzałki ciągłe na rycinie), a które należy traktować jako alternatywny, mniej dzisiaj udokumentowany wybór (strzałki przerywane na rycinie — patrz: ryc. 1). Na rycinie zwraca uwagę to, że polscy eksperci byli już nawet bardziej liberalni, jeśli chodzi o stopień zwężenia zastawki mitralnej, uznając, że jedynie istotne, ciężkie zwężenie tej zastawki stanowi przeciwwskazanie do stosowania NOAC.

2. NOAC zwiększają skuteczność i bezpieczeństwo leczenia przeciwzakrzepowego, po uwzględnieniu właściwości konkretnego leku, wieku i funkcji nerek pacjenta oraz możliwych interakcji z innymi lekami. Konieczne jest monitorowanie klirensu kreatyniny.

3. Wybór konkretnego leku przeciwzakrzepowego powinien wynikać z merytorycznej dyskusji z pacjentem uwzględniającej aspekty medyczne, ekonomiczne i współdziałanie terapeutyczne. Do aspektów medycznych, które mogą ukierunkować wybór leku, należą: funkcja nerek, bardzo wysokie ryzyko zakrzepowe lub wywiad zatorowości przy stosowaniu innego antykoagulantu oraz wysokie ryzyko krwotoczne.

Komentarz: Chociaż NOAC są dzisiaj lekami pierwszego wyboru w swojej klasie, nadal nie znamy odpowiedzi na pytanie, który z nich jest najlepszy. Nie istnieją bowiem i nie są prowadzone prospektywne badania typu "head-to-head" (lek porównywany bezpośrednio z innym lekiem w tej samej grupie). Powstało zatem dużo różnych prób pozycjonowania 


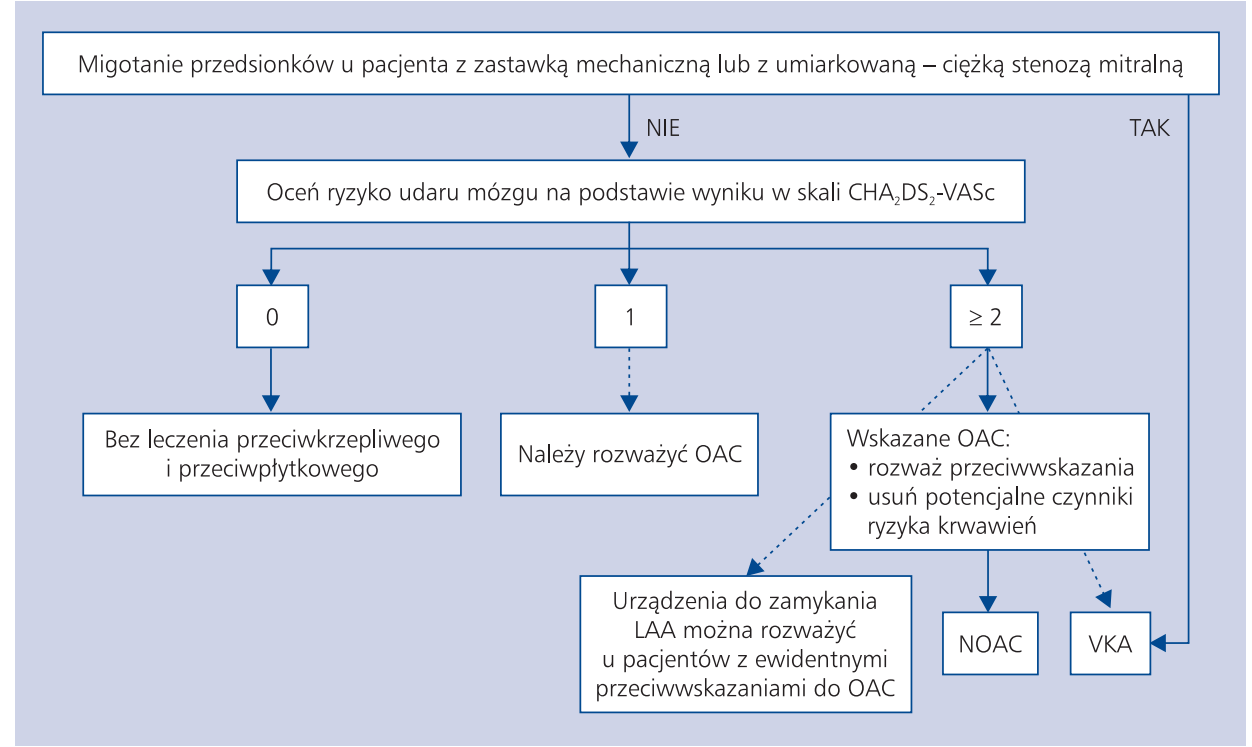

Rycina 1. Aktualne zalecenia europejskie (2016) dotyczące sposobu wyboru leczenia przeciwkrzepliwego w migotaniu przedsionków, zależne od punktów ryzyka w skali $\mathrm{CHA}_{2} \mathrm{DS}_{2}$-VASC; OAC — doustne leczenie przeciwkrzepliwe; LAA — uszko lewego przedsionka; NOAC — doustne leki przeciwkrzepliwe niebędące antagonistami witaminy K; VKA — antagoniści witaminy K (warfaryna/acenokumarol) (na podstawie: [2])

NOAC i algorytmów doboru tych leków opartych na elementach, o których wspominają polscy autorzy "dekalogu”. Obecnie w literaturze przedmiotu cytuje się najczęściej trzy różne propozycje oparte na trzech algorytmach, które zdobyły największą popularność. Warto jednak odnotować, że żadna z tych propozycji nie znalazła się w wytycznych europejskich, które pozostawiają dużą swobodę lekarzowi w zakresie podejmowania decyzji o wyborze konkretnego NOAC.

\section{Propozycja Savelievej-Camma z 2014 r. [3]}

Algorytm proponowany przez Savelievą i Camma sprowadza się do wyboru konkretnych NOAC do konkretnych sytuacji klinicznych, a mianowicie:

- wysokie ryzyko krwawienia, np. w skali HAS-BLED $\geq 3$ — wybierz dabigatran 110 mg lub apiksaban;

- wywiad krwawienia z przewodu pokarmowego lub bardzo duże ryzyko takiego krwawienia - wybierz apiksaban;

- wysokie ryzyko udaru przy niskim ryzyku krwawienia - wybierz dabigatran $150 \mathrm{mg}$;

- przebyty udar mózgu (prewencja wtórna) - wybierz riwaroksaban lub apiksaban;

- wywiad choroby wieńcowej, przebytego zawału serca lub wysokie ryzyko ostrych zespołów wieńcowych wybierz riwaroksaban;

— przewlekła niewydolność nerek — wybierz apiksaban lub riwaroksaban;

- dolegliwości ze strony przewodu pokarmowego/zaburzenia jelitowo-żołądkowe - wybierz apiksaban lub riwaroksaban;

- niechęć pacjenta do stosowania leku częściej niż raz na dobę - wybierz riwaroksaban.

\section{Propozycja Lipa i Lane'a z 2015 r. [4]}

Algorytm Lipa i Lane'a jest bardziej rozbudowany, obejmuje już także pozycjonowanie "najmłodszego" NOAC w grupie - edoksabanu. Proponuje się w nim następujące dobieranie konkretnych NOAC do konkretnych sytuacji klinicznych:

- nawracający udar mózgu/przemijający atak niedokrwienny mimo stosowania doustnych antykoagulantów starej generacji przy dobrej skuteczności laboratoryjnej tego leczenia - wybierz dabigatran 150 mg;

- umiarkowana i ciężka przewlekła choroba nerek (GFR 15-49 $\mathrm{ml} / \mathrm{min}$ ) - wybierz apiksaban lub riwaroskaban lub dabigatran $75 \mathrm{mg}$ lub edoksaban $30 \mathrm{mg}$;

- wysokie ryzyko krwawień z przewodu pokarmowego — wybierz apiksaban lub dabigatran $110 \mathrm{mg}$;

- zaburzenia żołądkowo-jelitowe i/lub objawy dyspepsji - wybierz apiksaban lub riwaroksaban lub edoksanban;

- wysokie ryzyko krwawienia, np. HAS-BLED $\geq 3$ - wybierz dabigatran 110 mg lub apiksaban lub edoksaban;

- preferowanie przez pacjenta przyjmowania leku raz na dobę - wybierz riwaroksaban lub edoksaban.

\section{Propozycja Maana i wsp. z 2015 r. [5]}

Algorytm proponowany przez Maana i wsp. ma dużą zaletę — jest bardzo uproszczony. Proponuje się w nim podział pacjentów na cztery grupy, w zależności od najważniejszej cechy: - wysokie ryzyko udaru, niskie ryzyko krwawienia (HAS-BLED < 3) - wybierz dabigatran 150 mg;

- wysokie ryzyko krwawienia HAS-BLED $\geq 3$ - wybierz apiksaban lub dabigatran $110 \mathrm{mg}$;

- przewlekła niewydolność nerek i/lub zaburzenia ze strony przewodu pokarmowego o typie dyspepsji i/lub 


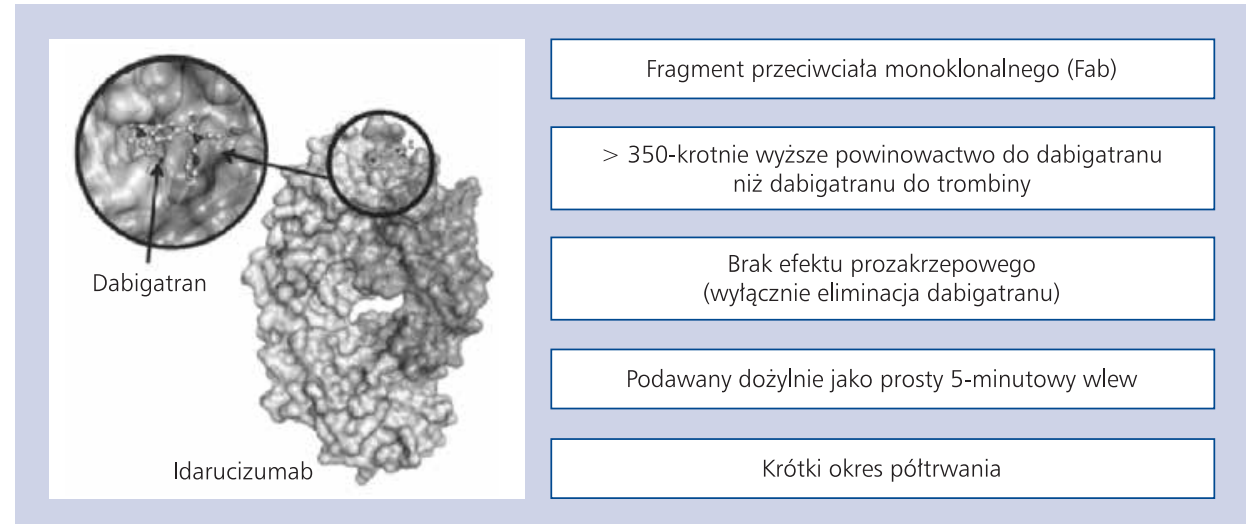

Rycina 2. Podsumowanie farmakologicznego działania i budowy idarucizumabu (na podstawie: Glund et al. Tromb Haemost, 2015; Schiele et al. Blood, 2013)

ryzyko krwawienia z przewodu pokarmowego — wybierz apiksaban lub riwaroksaban;

- preferowanie przez pacjenta przyjmowania leku raz na dobę - wybierz riwaroksaban.

4. Stosowanie doustnych bezpośrednich inhibitorów Ila oraz Xa nie wymaga rutynowego monitorowania parametrów krzepnięcia krwi.

5. Przy zmianie rodzaju leku przeciwzakrzepowego (VKA/NOAC) istotne znaczenie mają zachowanie ciągłej skuteczności leczenia i minimalizacja ryzyka powikłań krwotocznych na podstawie schematów kontroli wynikających z farmakokinetyki leków.

6. Kluczowe znaczenie dla opanowania krwawienia u pacjenta leczonego NOAC, przy ograniczonych możliwościach rutynowej oceny siły działania przeciwzakrzepowego, mają: pełna ocena kliniczna, identyfikacja podłoża krwawienia, oszacowanie czasu niezbędnego do eliminacji leku, próba wyrównania niedoborów czynników układu krzepnięcia, a w przypadku dabigatranu dodatkowo możliwość dializy lub podania swoistego antidotum - idarucizumabu.

Komentarz: Aktualna "wyższość dabigatranu” nad innymi NOAC w grupie, chociaż nie będzie trwała długo, polega na tym, że istnieje antidotum dla tego leku — idarucizumab. Podsumowanie cech farmakologicznych idarucizumabu przedstawiono na rycinie 2. Lek wprowadzono na rynek farmaceutyczny w Polsce w marcu 2016 r. i od tego czasu jest rozmieszczony już w ok. 200 placówkach szpitalnych w Polsce, czekając na zastosowanie zarówno w przypadku krwawień wymagających hospitalizacji, jak i wskazań związanych z przygotowaniem do nagłego zabiegu operacyjnego pacjenta będącego pod wpływem zażytego dabigatranu. Do końca października lek został zastosowany w Polsce w blisko 30 przypadkach (dane producenta), ale sama świadomość, że dostępne jest bezpieczne antidotum dla dabigatranu niewątpliwie sprzyja decyzjom o wyborze właśnie tego NOAC u wielu chorych.

7. Trzytygodniowa terapia NOAC może być stosowana w celu przygotowania chorego do kardiowersji, analogicznie jak w przypadku VKA — ze względu na krótsze działanie leków nowej generacji podstawowe znaczenie ma jednoznaczne potwierdzenie przez pacjenta nieprzerwanego przyjmowania leku, a w przypadku wątpliwości wykluczenie skrzepliny metodą echokardiografii przezprzełykowej.

Komentarz: Autorzy polskiego dokumentu sugerują lekarzom praktykom, aby udokumentowali „potwierdzenie przez pacjenta nieprzerwanego stosowania leku", np. w postaci notatki $w$ historii choroby z oświadczeniem pacjenta $i$ jego podpisem. Ma to wartość prawną w przypadku odstąpienia od echokardiografii przezprzełykowej i warto o tym pamiętać.

8. Przed zabiegiem ablacji migotania przedsionków należy podjąć decyzję o włączeniu leczenia NOAC na 3 tygodnie, kierując się punktacją w skali $\mathrm{CHA}_{2} \mathrm{DS}_{2}$ -VASc. Ze względu na brak jednoznacznych wyników badań randomizowanych NOAC należy odstawić przynajmniej 24 godziny przed zabiegiem ablacji (lub wcześniej, zależnie od funkcji nerek).

9. Rutynowe odstawianie leków przeciwzakrzepowych przed zabiegami o niskim ryzyku krwawień jest nieuzasadnione i może zwiększać ryzyko powikłań zakrzepowo-zatorowych.

10. Przygotowanie pacjenta leczonego za pomocą NOAC do zabiegu operacyjnego obarczonego istotnym ryzykiem krwawienia wymaga wiedzy o tempie eliminacji ostatniej podanej dawki leku (funkcja nerek), czasie 


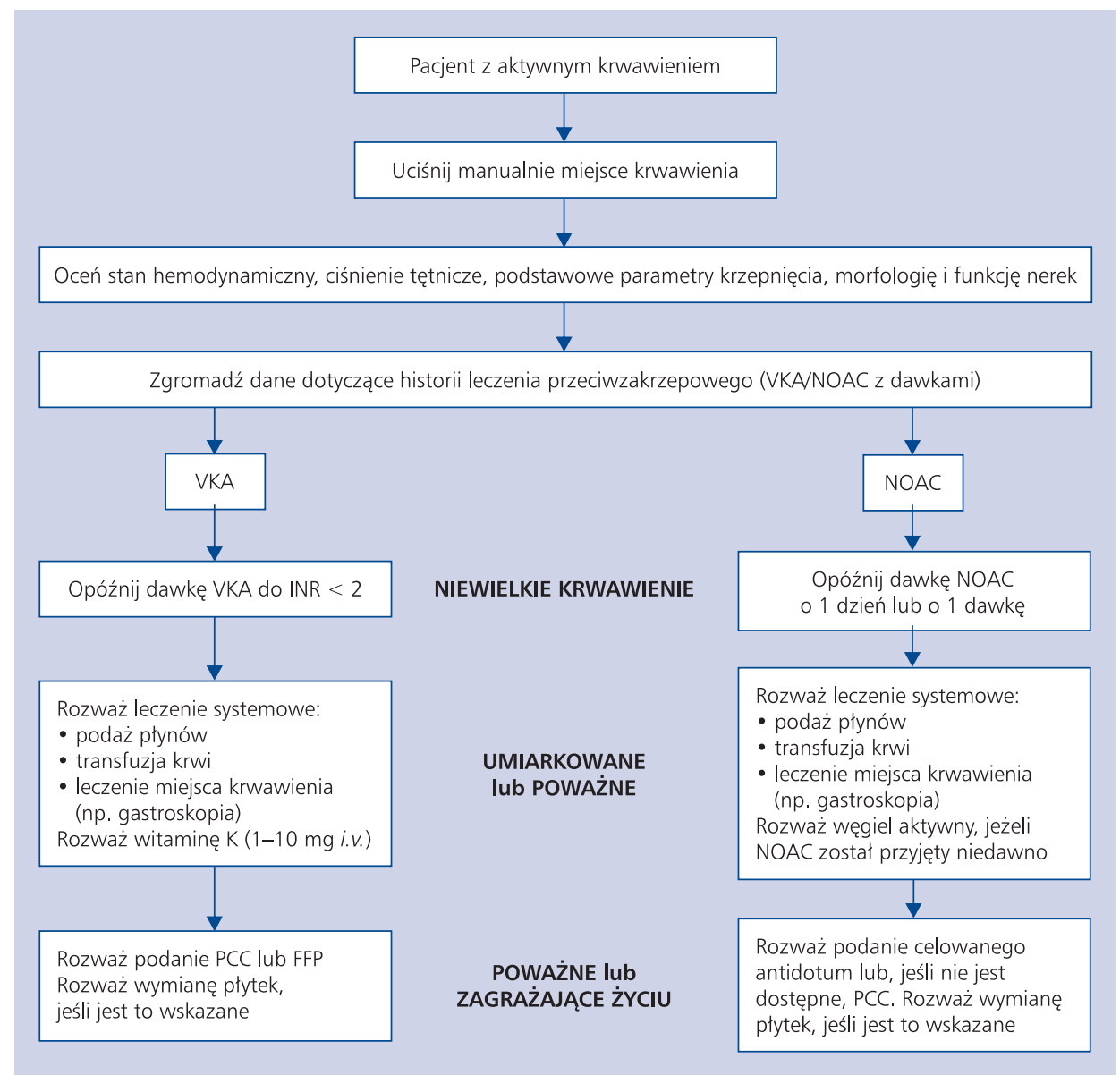

Rycina 3. Zalecane od sierpnia 2016 roku w Europie postępowanie w przypadku krwawienia u pacjentów stosujących doustne antykoagulanty; CCP — koncentrat czynników zespołu protrombiny; FFP — aktywowany koncentrat czterech czynników zespołu protrombiny; INR - międzynarodowy współczynnik znormalizowany; i.v. — dożylnie; NOAC — doustny lek przeciwkrzepliwy niebędący antagonistą witaminy K; VKA — antagonista witaminy K (na podstawie: [2])

możliwego odroczenia operacji i właściwościach stosowanego leku przeciwzakrzepowego, a w sytuacjach pilnych może wymagać interwencji farmakologicznej (podanie czynników krzepnięcia lub antidotum).

Komentarz: W aktualnych zaleceniach dotyczących postępowania w przypadku krwawienia w migotaniu przedsionków Europejskie Towarzystwo Kardiologiczne (ESC) zamieściło szczegółowy algorytm, w którym również znalazł się idarucizumab jako "celowane antidotum". Wykres ten zaprezentowano na rycinie 3.

Omówienie tego „polskiego dekalogu” jest, moim zdaniem, interesujące właśnie w kontekście znacznie szerszego poradnika EHRA; warto je również czytać wraz z najnowszymi wytycznymi Europejskiego Towarzystwa Kardiologicznego dotyczącymi migotania przedsionków [2].

W tej triadzie wytycznych i stanowisk (EHRA-ESC-Sekcja Farmakoterapii Sercowo-Naczyniowej PTK) można odnaleźć kilka nawzajem uzupełniających się informacji i wskazówek. Dlatego też warto znać wszystkie trzy dokumenty, chociaż niniejszy suplement, który trzyma w dłoniach
Czytelnik „Kardiologii Polskiej”, ma w swoim zamyśle zwrócić uwagę przede wszystkim na tytułowy poradnik EHRA.

Konflikt interesów: Honoraria wykładowe następujących producentów NOAC: Bayer, Boehringer Ingelheim, MSD, Pfizer.

\section{Piśmiennictwo}

1. Kasprzak JD, Dąbrowski R, Barylski M et al. Doustne antykoagulanty nowej generacji — aspekty praktyczne. Stanowisko Sekcji Farmakoterapii Sercowo-Naczyniowej Polskiego Towarzystwa Kardiologicznego. Folia Cardiol, 2016; 11: 1-17.

2. Kirchhof P, Benussi S, Kotecha D et al. 2016 ESC Guidelines for the management of atrial fibrillation developed in collaboration with EACTS. Eur Heart J, 2016; Aug 27. pii: ehw210. [Epub ahead of print].

3. Savelieva I, Camm AJ. Practical considerations for using novel oral anticoagulants in patients with atrial fibrillation. Clin Cardiol, 2014; 37: 32-47.

4. Lip GY, Lane DA. Matching the NOAC to the patient: remember the modifiable bleeding risk factors. J Am Coll Cardiol, 2015; 66: 2282-2284.

5. Maan A, Heist EK, Ruskin JN, Mansour M. Practical issues in the management of novel oral anticoagulants - cardioversion and ablation. J Thorac Dis, 2015; 7: 115-131. 